$\mathrm{UH}$

iti Universität Hamburg
Faculty Economics and Social Sciences Chair for Economic Policy

INVESTMENT IN STADIA AND REGIONAL

ECONOMIC DEVELOPMENT- EVIDENCE FROM

FIFA WORLD CUP 2006 STADIA

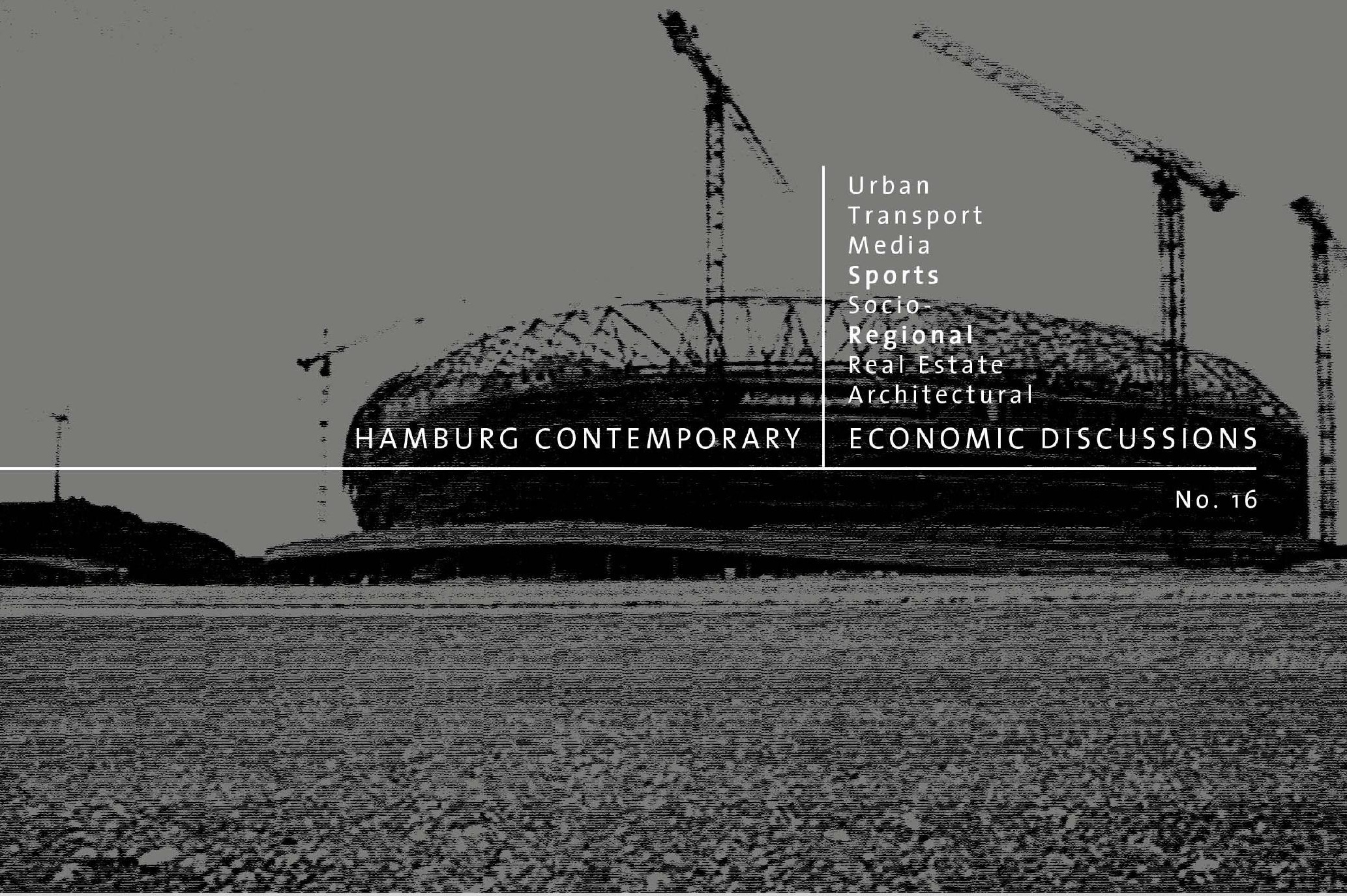


Hamburg Contemporary Economic Discussions

University of Hamburg

Faculty Economics and Social Science

Chair for Economic Policy

Von-Melle-Park 5

D-20146 Hamburg | Germany

Tel $+494042838-4622$

$\mathrm{Fax}+494042838-6251$

http://www.uni-hamburg.de/economicpolicy/

Editor: Wolfgang Maennig

Arne Feddersen

University of Hamburg

Faculty Economics and Social Science

Chair for Economic Policy

Von-Melle-Park 5

D-20146 Hamburg | Germany

Tel $+494042838-4628$

Fax +494042838 - 6251

feddersen@econ.uni-hamburg.de

André L. Grötzinger

University of Hamburg

Faculty Economics and Social Science

Von-Melle-Park 5

D-20146 Hamburg | Germany

Wolfgang Maennig

University of Hamburg

Faculty Economics and Social Science

Chair for Economic Policy

Von-Melle-Park 5

D-20146 Hamburg | Germany

Tel $+494042838-4622$

$\mathrm{Fax}+494042838-6251$

maennig@econ.uni-hamburg.de

ISSN 1865 - 2441 (Print)

ISSN 1865 - 7133 (Online)

ISBN 978 - 3 - 940369 - 46 - 8 (Print)

ISBN 978 - 3 - $940369-47$ - 5 (Online) 


\title{
Investment in Stadia and Regional Economic Development - Evidence from FIFA World Cup 2006
}

\begin{abstract}
Using the case of the new stadiums for the FIFA World Cup 2006 in Germany, this paper is the first multivariate work that examines the potential income and employment effects of new stadiums outside of the USA. This study is also the first work on this topic that conducts tests on the basis of a (serial correlation consistent) Difference-in-Difference model with level and trends. As a robustness check, we use the "ignoring time series information" model in a form that is modified for nonsynchronous interventions. We were not able to identify income or employment effects of the construction of new stadiums for the FIFA World Cup 2006, which are significantly different from zero.
\end{abstract}

Keywords: Sports Economics, Regional Economics, Stadia Infrastructure, Difference-in-Difference Model JEL classification: $\mathrm{H} 54, \mathrm{~L} 83, \mathrm{R} 12, \mathrm{R} 53$

Version: October 2008

\section{Introduction}

A series of studies on Metropolitan Statistical Areas (MSAs) in the USA revealed that new sport stadiums do not generate significant income and/or employment effects in their host cities, ${ }^{1}$ challenging the "boosters" view of many politicians and sport officials who claim beneficial effects for the local economy (and hence, a justification for public financial support).

Using the case of the new stadiums for the FIFA World Cup 2006 in Germany, this paper is the first multivariate work that examines the potential income and employment effects of new stadiums outside of the USA. Such a study is generally interesting set against the background of the different urban structures in the USA and Europe. In addition, a non-US study is especially interesting because of decade-long US tradition of allocating the stadiums in suburban areas, whereas

See BAADE (1987, 1994, 1996), BAADE \& DYE (1990), BAADE \& SANDERSON (1997), COATES \& HUMPHREYS (1999, 2000, 2001, 2003). 
European stadiums are mostly located near to the city center (FEDDERSEN \& MAENNIG, 2008). NELSON (2001) argued that (US-)studies concluding insignificant effects on the home cities of stadiums are misleading, since the data are based on stadia built in the 1960s-1980s. On closer examination of the economic impact, it is evident that stadiums built in Central Business Districts (CBD) or downtown sites have a positive effect, while for suburban stadiums the effects on regional economic development are insignificant or even negative. ${ }^{2}$

This study is also the first work on this topic that conducts tests on the basis of a Difference-in-Difference (DD) model with levels and trends. To address the problem of potential serial correlation in DD models (BERTRAND, DUFLO, \& MULLAINATHAN, 2004), we use a serial correlation consistent arbitrary variancecovariance matrix. As robustness check we use the "ignoring time series information" (ITSI) model in a form that is modified for non-synchronous interventions. The paper is organized as followed. Section 2 elaborates on the data, section 3 presents methods and results, and section 4 concludes.

\section{Data}

The FIFA World Cup 2006 in Germany was held in 12 different stadiums (Berlin, Cologne, Dortmund, Frankfurt, Gelsenkirchen, Hamburg, Hannover, Kaiserslautern, Leipzig, Munich, Nuremberg, Stuttgart). The investment costs for new construction or major renovations totaled an amount of nearly $€ 1.6$ billion for twelve stadiums (FIFA, 2006). ${ }^{3}$ Additional $€ 1.6$ billion was invested into stadia related infrastructure (BÜTTNER, MAENNIG, \& MENßEN, 2005). As the aim of this analysis is to identify the effects of the FIFA World Cup stadiums, these twelve cities will be used as the treatment group in the DD model. During the period of observation, several additional stadium construction projects were undertaken in Ger-

MELANIPHY (1996) and SANTEE (1996) also argued that stadiums in inner cities might be more efficient for the regional development of these cities.

3 Every World Cup stadium was at least renovated. The average expenditure per city was $€ 116.7$ million with a minimum investment of $€ 36.0$ million (Dortmund) and a maximum investment of $€ 280.0$ million (Munich). 
many. To avoid biased results, in addition to the FIFA World Cup stadiums, all relevant stadium construction projects (including the FIFA World Cup stadiums) were used as the treatment group in a second DD regression.

Tab. 1 Relevant Stadium Construction Projects in Germany, 1996 to 2005

\begin{tabular}{|c|c|c|c|c|c|c|}
\hline \multirow{2}{*}{ City } & \multirow{2}{*}{ Stadium } & \multirow{2}{*}{ Capacity } & \multirow{2}{*}{ Team(s) } & \multirow{2}{*}{ Costs } & \multicolumn{2}{|c|}{ Construction } \\
\hline & & & & & Start & End \\
\hline Berlin & Olympiastadion & 74,000 & Hertha BSC Berlin & 242.0 & Aug 2000 & Aug 2004 \\
\hline Bremen & Weserstadion & 42,100 & Werder Bremen & 18.0 & May 2003 & Jul 2004 \\
\hline Cologne & RheinEnergy-Stadion & 50,374 & 1. FC Köln & 117.5 & Jan 2002 & Jul 2004 \\
\hline Cottbus & Stadion der Freundschaft & 22,746 & FC Energie Cottbus & 12.0 & Apr 2002 & Jul 2003 \\
\hline Dortmund & Signal Iduna Park & 83,000 & Borussia Dortmund & 36.0 & May 2002 & Jul 2003 \\
\hline Düsseldorf & LTU arena & 52,000 & Fortuna Düsseldorf & 218.0 & Sep 2002 & Jan 2005 \\
\hline Duisburg & MSV-Arena & 31,514 & MSV Duisburg & 43.0 & Oct 2003 & Jan 2005 \\
\hline Frankfurt & Commerzbank-Arena & 51,500 & Eintracht Frankfurt & 126.0 & Jul 2002 & May 2005 \\
\hline Gelsenkirchen & Veltins-Arena & 61.524 & FC Schalke 04 & 192.0 & Nov 1998 & Jul 2001 \\
\hline Hamburg & HSH-Nordbank-Arena & 57,000 & Hamburger SV & 97.0 & Jun 1998 & Aug 2000 \\
\hline Hannover & AWD-Arena & 49,000 & Hannover 96 & 63.0 & Feb 2003 & Jan 2005 \\
\hline Kaiserslautern & Fritz-Walter-Stadion & 48,500 & 1, FC Kaiserslautern & 48.3 & Aug 2004 & Apr 2006 \\
\hline Leipzig & Zentralstadion & 44,193 & Sachsen Leipzig & 90.6 & Dec 2000 & March 2004 \\
\hline Magdeburg & Stadion Magdeburg & 27,000 & 1, FC Magdeburg & 30.9 & March 2005 & Dec 2006 \\
\hline Mönchengladbach & Borussia-Park & 54,057 & Borussia M'gladbach & 87.0 & Jan 2002 & Jul 2004 \\
\hline Munich & Allianz Arena & 69,901 & FC Bayern München & 280.0 & Feb 2002 & May 2005 \\
\hline Nuremberg & easyCredit-Stadion & 46,780 & 1, FC Nürnberg & 56.0 & Nov 2003 & Jul 2005 \\
\hline Rostock & DKB-Arena & 30000 & FC Hansa Rostock & 55.0 & May 2000 & Aug 2001 \\
\hline Stuttgart & Gottlieb-Daimler-Stadion & 55,896 & VfB Stuttgart & 51.6 & Jan 2004 & Jan 2006 \\
\hline Wolfsburg & Volkswagen Arena & 29,161 & VfL Wolfsburg & 51.0 & May 2001 & Nov 2002 \\
\hline
\end{tabular}

Source: SKRENTNY (2001); FIFA (2006); STADIONWELT (2007); FIFA World Cup 2006 stadia are marked in bold letters.

The analytical framework for this study comprises data of the 118 most populated large urban districts ("Kreisfreie Städte") in Germany in 1995, as reported by the ARBEITSKREIS VOLKSWIRTSCHAFTLICHE GESAMTRECHNUNG DER LÄNDER (2007b). ${ }^{4}$ As variables for the regional economic development, the income of private households per capita (ARBEITSKREIS VOLKSWIRTSCHAFTLICHE GESAM-

4 See Table A1 in the annex for a complete list of the large urban districts. 
TRECHNUNGEN DER LÄNDER, 2007b) as well as the number of people employed (ARBEITSKREIS VOLKSWIRTSCHAFTLICHE GESAMTRECHNUNGEN DER LÄNDER, 2007a) in these 118 large urban districts are considered.

Fig. 1. Large Urban Districts in Germany and Stadia Construction Projects

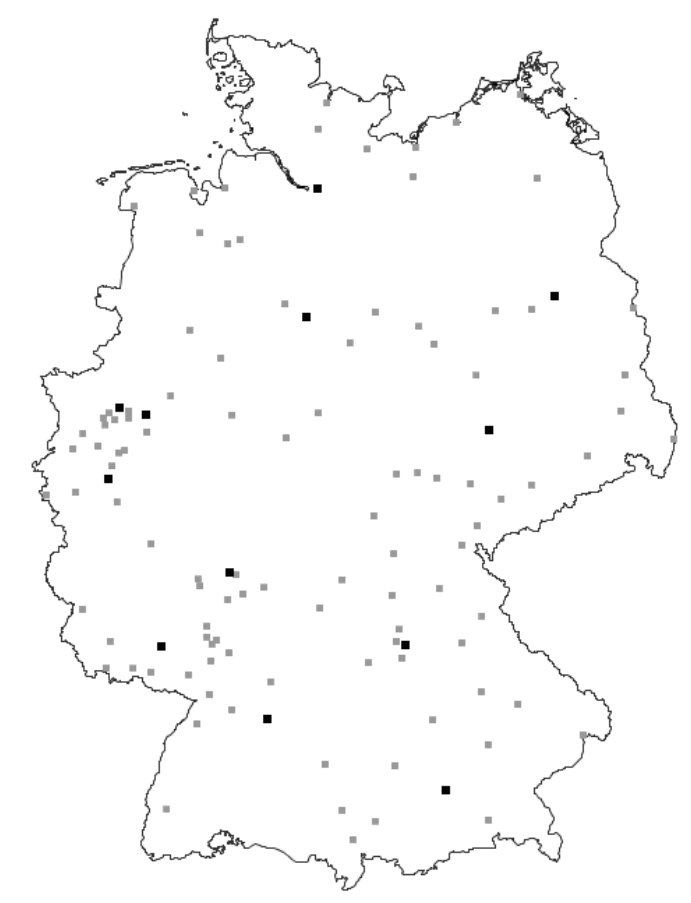

Notes: World Cup venues are marked in black, German large urban districts are marked in grey. Own illustration.

For the income of private households, the period of observation is 1995 to 2005 , i.e. a time Span of 11 years; the period from 1996 to 2005, i.e. a time Span of ten years, is considered for employment data. As the data availability starts in 1995, no structural breaks due to German reunification have to be considered. ${ }^{5}$

Several additional indicators of the regional economic development could be considered. HOTCHKISS, MOORE, \& ZOBAY (2003), for instance, suggested that the DD equation could be estimated for population. As one easily can see, a sport venue or sport franchise (sport club) might increase the attractiveness of a city from

Start and end of the observation periods are determined by data availability from EUROSTAT and VGRDL. 
a resident's point of view. As a consequence, migration into the city may occur. Thus, initially, it might be appropriate to test for a population effect. However, since it is difficult to assume that unemployed persons will migrate due to the increased attractiveness of a city, we can assume that most migrants will be working in their new city. Thus a strong correlation between population and employment exists and an additional DD analysis on population is unnecessary.

\section{Method and Results}

\subsection{DD Model with Level and Trend}

The aim of this paper is to examine if stadium construction projects in Germany - especially those of the FIFA World Cup 2006 - have a significant impact on the economic development of the regions in which they are located. For this purpose, we use a DD estimation. This is a common approach for identifying the effect of a specific intervention or treatment. Therefore, one has to compare the differences in outcome before and after an intervention for groups affected by the intervention to the difference for unaffected groups (BERTRAND, DUFLO, \& MULLAINATHAN, 2004, p. 249).

We focus our interest on differences in levels and trends for two variables: employment and income. Since the stadium construction work did not start at the same point in time for all cities (see Table 1) the pre-period and the post-period are not the same for all cities of the treatment group, and they are not even defined for the control cities. Thus, in contrast to many DD models, ${ }^{6}$ no dummy variable for the post-period of all cities will be included. Equation (1) and (2) contain the modified DD model:

$$
\begin{gathered}
Z_{i t}=\alpha+\beta_{1} P T_{i t}+\beta_{2} \text { trend }+\beta_{3} T T_{i t}+\beta_{4} P T T_{i t}+\varepsilon_{i t} \\
\text { with } \varepsilon_{i t}=\mu_{i}+v_{i t}
\end{gathered}
$$

\footnotetext{
See e.g. HAGN \& MAENNIG (2008a, 2008b), JASMAND \& MAENNIG (2008) or HOTCHKISS,
} MOORE, \& ZOBAY (2003) for the use of a general post period dummy. 
where $Z_{i t}$ is the income of private households in city $i$ in year $t$ or the employment in city $i$ in year $t$, respectively. $\alpha$ denotes the intercept term. trend is a trend variable for all 118 large urban districts starting with the value of one in year 1995 (1996) and ends with a value of eleven (ten) in year 2005. No dummy variable for the treatment group is included because our model is a fixed effects model with separate dummies for all large urban districts capturing the treatment group effects. $P T_{i t}$ is a dummy for the post intervention phase of the treatment group. It takes the value of one for cities with relevant stadia construction projects from the year of the start of the construction work ${ }^{7}$ and zero otherwise. $P T T_{i t}$ denotes a variable that covers a post period trend for the treatment cities. It is the product of the variables $P T_{i t}$ and trend. In the years before the start of the construction project it takes the value of zero and afterwards it displays the corresponding value of the trend variable. $\beta_{1}, \beta_{2}, \beta_{3}$, and $\beta_{4}$ are coefficients to be estimated. $\mu_{i}$ covers the unobserved individual specific effects (fixed effects) while $v_{i t}$ denotes the remainder disturbance.

The coefficients of interests are $\beta_{1}$ and $\beta_{4}$ since they are measuring the level and trend effect of the intervention (stadium construction project) of the treatment cities. If a stadium construction project produces an impact on employment and income, then these coefficients need to be significant. Due to need for workers to accomplish the construction, the demand for employees will increase. Thus, a positive sign of the level effect $\left(P T_{i t}\right)$ could be found in the employment model.

In contrast, the trend effect on income per capita is theoretically ambiguous. If we assume that the attractiveness of a city increase in the eyes of residents and nonresidents (for example, because of an eye-catching new stadium and its asso-

As the employment and income data are on a yearly basis and as the construction work does not always starts at the beginning of year, no effect could be found for a year in which a construction project starts at the year's end. To deal with this problem, stadium constructions will be considered only for a specific year if the start of work lies in first three quarters of this year. If the construction work started in the last quarter of a year, the following year will be treated as starting point. 
ciated feel-good effects ${ }^{8}$ ), then migration into the city may occur. If the population increases, the labor supply might increase, potentially leading to decreasing wages (“compensating differentials", CARLINO \& COULSON, 2004).

To isolate the effect of the pure construction phase, a second variant of model (1) will be estimated:

$$
\begin{gathered}
Z_{i t}=\alpha+\beta_{1} P T_{i t}+\beta_{2} C+\beta_{3} \text { trend }+\beta_{4} T T_{i t}+\beta_{5} P T T C_{i t}+\varepsilon_{i t} \\
\text { with } \varepsilon_{i t}=\mu_{i}+v_{i t}
\end{gathered}
$$

The variables trend, $T T_{i t}$ and $P T_{i t}$ are identical to those in model (1). To isolate the effects of the construction phase, the dummy variable $C$ takes the value of one during the construction work and the value of zero otherwise. ${ }^{9}$ PTTC $_{i t}$ is a post intervention trend for the treatment group that starts after the construction work has finished since we expect that changes in the growth trend will occur not due to the construction but, rather, due to advancements in the attractiveness of the city that are derived only from the completed stadium. It has to be admitted, though, that, due to data limitations, for some stadia projects (e.g. Kaiserslautern or Stuttgart) only a few observations are available for PTTC, making it statistically demanding to isolate any post-construction effects for these cities.

As shown by BERTRAND, DUFLO, \& MULLAINATHAN (2004), DD models are frequently subject to serial correlation, which might lead to an overestimation of the significance of the "intervention" dummy. To check for such problems, we performed an LM test for serial correlation in a fixed effects model as suggested by BALTAGI (2001, pp. 94-95). ${ }^{10}$ This test is performed on the residuals of standard

8 See MAENNIG (2006) for on overview of the effects of iconic architecture of sporting venues and MAENNIG \& PORSCHE (2008) for a first contribution dealing with the feel-good effects of large sporting events.

9 The periods of construction can be found in columns 6 and 7 of Table 1. As construction work is not always started at the beginning of a year, the dummy takes the value of one if the works starts before October or does not end before April of the respective year.

${ }^{10}$ The $L M$ test statistic is $L M_{5}=\sqrt{N T^{2} /(T-1)\left(\tilde{v}^{\prime} \tilde{v}_{-1} / \tilde{v}^{\prime} \tilde{v}\right)}$, which is asymptotically distributed as $N(0,1)$. 
fixed effects regressions of the above described models (1) and (2) for income and employment. ${ }^{11}$

\section{Tab. 2 Test for Serial Correlation}

\begin{tabular}{ccccc}
\hline \hline \multirow{2}{*}{$\begin{array}{c}\text { Endogenous } \\
\text { variable }\end{array}$} & Treatment WC & Treatment ALL & Treatment WC & Treatment ALL \\
\hline Income & 23.411 & 23.413 & 23.249 & 23.251 \\
Employment & 33.964 & 23.186 & 23.367 & 23.371 \\
\hline
\end{tabular}

Notes: "“" $p<0.01, " p<0.05, " p<0.10$.

The LM statistic indeed rejects the null hypothesis of no serial correlation in each case.

For such a case, BERTRAND, DUFLO, \& MULLAINATHAN (2004) suggest using an arbitrary variance-covariance matrix, which is consistent in the presence of any correlation pattern within cross section over time. Table 3 and Table 4 show the regression results of the DD coefficients and the corresponding t-statistics computed using an arbitrary variance-covariance matrix.

${ }^{11}$ The "intervention" coefficients of these regressions are often significant. But in the line with BERTRAND, DUFLO, \& MULLAINATHAN (2004) the estimates might be inefficient. 
Tab. 3 DD Model with Fixed Effects for Income of Private Households

\begin{tabular}{|c|c|c|c|c|}
\hline & \multicolumn{2}{|c|}{ Model (1) } & \multicolumn{2}{|c|}{ Model (2) } \\
\hline & $\begin{array}{l}\text { Treatment } \\
\text { WC } 12\end{array}$ & $\begin{array}{c}\text { Treatment } \\
\text { ALL } 20 \\
\end{array}$ & $\begin{array}{l}\text { Treatment } \\
\text { WC } 12\end{array}$ & $\begin{array}{c}\text { Treatment } \\
\text { ALL } 20 \\
\end{array}$ \\
\hline Constant & $\begin{array}{c}9.5511^{\cdots} \\
(3,539.662)\end{array}$ & $\begin{array}{r}9.550 \\
(3,663.220)\end{array}$ & $\begin{array}{c}9.551 \\
(3,502.198)\end{array}$ & $\begin{array}{c}9.551 \\
(3,594.649)\end{array}$ \\
\hline$P$ & $\begin{array}{r}-6.109 e^{-4} \\
(-0.432)\end{array}$ & $\begin{array}{c}6.297 e^{-4} \\
(0.733)\end{array}$ & $\begin{array}{c}-0.017 \\
(-1.257)\end{array}$ & $\begin{array}{l}-0.020 \\
(-1.787)\end{array}$ \\
\hline C & - & - & $\begin{array}{c}-0.005 \\
(-0.694)\end{array}$ & $\begin{array}{l}-0.008 \\
(-1.742)\end{array}$ \\
\hline trend & $\begin{array}{c}0.019 \\
(38.905)\end{array}$ & $\begin{array}{r}0.019 \\
(37.428)\end{array}$ & $\begin{array}{c}0.019 \\
(38.897)\end{array}$ & $\begin{array}{c}0.019 \\
(37.413)\end{array}$ \\
\hline TT & $\begin{array}{l}-0.005 \\
(-0.465)\end{array}$ & $\begin{array}{c}-0.008 \\
(-0.820)\end{array}$ & $\begin{array}{r}-8.063 e^{-4} \\
(-0.528)\end{array}$ & $\begin{array}{r}2.243 e^{-4} \\
(0.213)\end{array}$ \\
\hline PTT & $\begin{array}{c}8.260 \mathrm{e}^{-4} \\
(0.201)\end{array}$ & $\begin{array}{r}-7.980 e^{-5} \\
(-0.018)\end{array}$ & - & - \\
\hline PTTC & - & - & $\begin{array}{c}0.010 \\
(1.365)\end{array}$ & $\begin{array}{c}0.009 \\
(1.228)\end{array}$ \\
\hline $\mathrm{R}^{2}$ & 0.881 & 0.881 & 0.882 & 0.882 \\
\hline $\operatorname{adj} . R^{2}$ & 0.881 & 0.881 & 0.881 & 0.881 \\
\hline F-Stat & $441.250^{\cdots}$ & $550.130 \cdots$ & $352.928^{\cdots *}$ & $374.450^{\cdots *}$ \\
\hline $\mathrm{N}$ & 118 & 118 & 118 & 118 \\
\hline $\mathrm{T}$ & 11 & 11 & 11 & 11 \\
\hline $\mathrm{N}^{*} \mathrm{~T}$ & 1298 & 1298 & 1298 & 1298 \\
\hline
\end{tabular}


Tab. 4 DD Model with Fixed Effects for Employment

\begin{tabular}{|c|c|c|c|c|}
\hline & \multicolumn{2}{|c|}{ Model (1) } & \multicolumn{2}{|c|}{ Model (2) } \\
\hline & $\begin{array}{l}\text { Treatment } \\
\text { WC } 12\end{array}$ & $\begin{array}{c}\text { Treatment } \\
\text { ALL } 20 \\
\end{array}$ & $\begin{array}{c}\text { Treatment } \\
\text { WC } 12 \\
\end{array}$ & $\begin{array}{c}\text { Treatment } \\
\text { ALL } 20 \\
\end{array}$ \\
\hline Constant & $\begin{array}{c}11.2444^{* * *} \\
(1,804.627)\end{array}$ & $\begin{array}{c}11.245^{\cdots *} \\
(1,954.357)\end{array}$ & $\begin{array}{c}11.245 \\
(1,950.524)\end{array}$ & $\begin{array}{r}11.244 \\
(1,868.912)\end{array}$ \\
\hline$P$ & $\begin{array}{c}0.006 \\
(0.723)\end{array}$ & $\begin{array}{c}0.015 \\
(1.106)\end{array}$ & $\begin{array}{c}0.015 \\
(0.623)\end{array}$ & $\begin{array}{c}0.002 \\
(0.100)\end{array}$ \\
\hline C & - & - & $\begin{array}{c}-0.009 \\
(-1.159)\end{array}$ & $\begin{array}{c}-0.010 \\
(-1.371)\end{array}$ \\
\hline trend & $\begin{array}{c}2.189 \mathrm{e}^{-4} \\
(0.222)\end{array}$ & $\begin{array}{r}3.647 e^{-4} \\
(0.375)\end{array}$ & $\begin{array}{r}9.702 \mathrm{e}^{-4} \\
(0.003)\end{array}$ & $\begin{array}{r}2.189 e^{-4} \\
(0.222)\end{array}$ \\
\hline TT & $\begin{array}{c}0.006 \\
(1.494)\end{array}$ & $\begin{array}{c}0.005 \\
(1.224)\end{array}$ & $\begin{array}{c}0.004 \\
(1.089)\end{array}$ & $\begin{array}{c}0.005 \\
(1.413)\end{array}$ \\
\hline PTT & $\begin{array}{c}-0.008 \\
(-1.523)\end{array}$ & $\begin{array}{c}-0.006 \\
(-1.146)\end{array}$ & - & - \\
\hline PTTC & - & - & $\begin{array}{c}-0.001 \\
(-0.071)\end{array}$ & $\begin{array}{c}-0.007 \\
(-0.525)\end{array}$ \\
\hline $\mathrm{R}^{2}$ & 0.979 & 0.979 & 0.979 & 0.979 \\
\hline Adj. $R^{2}$ & 0.979 & 0.979 & 0.978 & 0.978 \\
\hline F-Stat & $10,256.240^{\ldots *}$ & $10,330.930^{\cdots *}$ & $9,620.552^{\cdots *}$ & $9,596.174$ \\
\hline $\mathrm{N}$ & 118 & 118 & 118 & 118 \\
\hline $\mathrm{T}$ & 10 & 10 & 10 & 10 \\
\hline $\mathrm{N}^{*} \mathrm{~T}$ & 1180 & 1180 & 1180 & 1180 \\
\hline
\end{tabular}

Notes: $" p<0.01, " p<0.05, p<0.10 . t$-statistics are in parentheses. Standard errors are computed using an arbitrary variance-covariance matrix as suggested by BERTRAND, DUFLO, \& MULLAINATHAN (2004, pp. 270-272).

In all four estimated income models, the trend variable trend is significant at the $1 \%$-level, while it is not significant for the employment estimations. Not surprisingly, this means that there is a positive trend in income for all regarded 118 German large urban districts within the observation period. The treatment trend dummy is insignificant in all models, implying that there is no systematic difference between the treatment and control groups in the growth pattern of urban districts. The coefficients of the post-period dummy PT of the treatment urban districts and the respective coefficient of the post-trend dummy PTT - the objects 
of interest - are insignificant for all estimations. The results are not affected by accounting for a special construction effect, as shown in model (2) of the income and employment regressions. Thus, the hypothesis of no income and employment effect of the stadia construction projects in the 12 respectively 20 urban districts with completed stadia construction cannot be rejected.

\subsection{Ignoring Time Series Information DD Model}

To check robustness, we will use the "ignoring time series information" (ITSI) model in its modification for non synchronous interventions (BERTRAND, DUFLO, \& MULLAINATHAN, 2004, pp. 267-269). In a first step, $Z_{i t}$ (equation 1 and 2) was regressed on city fixed effects, time fixed effects and relevant covariates. ${ }^{12}$ In the second step, the residuals of only the treatment group will be taken into account. These residuals will be divided into two groups: (1) residuals from years before the start of a stadia construction project, and (2) residuals from years after the start of a stadia construction project. The stadia effect can then be analyzed by an OLS regression of a two-period regression of the residuals from the treatment cities only. Consistent $t$-statistics can be obtained from this OLS regression. ${ }^{13}$

Tab. 5 ITSI DD Model for Income of Private Households

\begin{tabular}{cccccc}
\hline \hline & \multicolumn{2}{c}{ Model (1) } & & \multicolumn{2}{c}{ Model (2) } \\
\cline { 2 - 3 } \cline { 5 - 6 } \cline { 5 - 6 } Constant & Treatment WC & Treatment ALL & & Treatment WC & Treatment ALL \\
& $(1.081)$ & 0.020 & & 0.047 & 0.022 \\
& -0.006 & $(0.596)$ & & $(1.111)$ & $(0.635)$ \\
POST & $(-0.102)$ & -0.001 & & -0.005 & -0.001 \\
& 0.045 & $(-0.030)$ & & $(-0.084)$ & $(-0.020)$ \\
$R^{2}$ & 0.001 & 0.019 & & 0.030 & 0.024 \\
adj. $R^{2}$ & 0.007 & & 0.014 & 0.002 \\
\hline
\end{tabular}

Notes: $" p<0.01, " p<0.05, p<0.10 . t$-statistics are in parentheses. Coefficients are from a twostep process using OLS.

${ }^{12}$ As done in the previous section, two different variants have been analyzed: (1) no covariates are considered; (2) only a construction dummy is considered.

${ }^{13}$ As the numbers of cities is not small, the $t$-statistics don't have to be adjusted (BERTRAND, DUFLO, \& MULLAINATHAN, 2004). 
Tab. 6 ITSI DD Model for Employment

\begin{tabular}{cccccc}
\hline \hline & \multicolumn{2}{c}{ Model (1) } & & \multicolumn{2}{c}{ Model (2) } \\
\cline { 2 - 3 } \cline { 5 - 6 } \cline { 5 - 6 } Constant & $1.573^{* * *}$ & $1.192^{* * *}$ & & $1.577^{* * *}$ & $1.196^{* * *}$ \\
& $(6.016)$ & $(5.734)$ & & $(6.050)$ & $(5.760)$ \\
POST & -0.008 & -0.004 & & -0.014 & -0.003 \\
& $(-0.022)$ & $(-0.013)$ & & $(-0.039)$ & $(-0.010)$ \\
$R^{2}$ & 0.095 & 0.057 & & 0.035 & 0.016 \\
adj. $R^{2}$ & 0.054 & 0.032 & & 0.009 & 0.010 \\
\hline
\end{tabular}

Notes: “ $p<0.01, " p<0.05, p<0.10 . t$-statistics are in parentheses. Coefficients are from a twostep process using OLS.

The results of the ITSI models as shown in Table 5 and Table 6 confirm the findings of the DD model estimated in section 3.1. No coefficient in the ITSI models is significant on any conventional level. The results of the robustness check support the results from the DD model using an arbitrary variance-covariance matrix.

\section{Conclusion}

We were not able to identify income or employment effects of the construction of the new stadiums for the World Cup 2006, which are significantly different from zero, in the urban districts with completed new stadiums in the period leading up to and after the FIFA World Cup 2006.

We nevertheless hesitate to share the concern expressed both implicitly and explicitly in many of the comparable sports economic studies that the positive effects of new stadiums claimed by many sports protagonists are not true for three reasons. Firstly, other effects such as the feel-good benefit for the population and/or image effects that are difficult to quantify, may be sufficiently important to justify major new stadiums and/or subsidies for them via public funds. With 
image effects and feel-good effects, economic empiricism in regards to sports is still in its infancy. ${ }^{14}$

Secondly, the treatment group in the selected form of municipality areas might be still too large and too highly aggregated to statistically prove significant effects. Studies on the effects of major sports venues on property values in surrounding areas indicate a maximum affect area of around 3,000 metres (AHLFELDT \& MAENNIG, 2007a, 2007b; TU, 2005).

${ }^{14}$ For the measurement of the benefit of the Olympic Games in London $2012 \mathrm{cf}$. ATKINSON et al. (2008); for the measurement of the willingness to pay for the Soccer World Cup 2006 (before and after the event) cf. HEYNE, MAENNIG, \& SÜßMUTH (2007). 


\section{Appendix}

Tab. A1. Population of the 118 largest urban districts ("kreisfreie Städte") in Germany in 1995

\begin{tabular}{|c|c|c|}
\hline No. & City & Popultion in 1995 \\
\hline 1 & Berlin & $3,471,003$ \\
\hline 2 & Hamburg & $1,707,251$ \\
\hline 3 & München & $1,240,465$ \\
\hline 4 & Köln & 964,597 \\
\hline 5 & Frankfurt am Main & 651,097 \\
\hline 6 & Essen & 616,340 \\
\hline 7 & Dortmund & 599,966 \\
\hline 8 & Stuttgart & 586,954 \\
\hline 9 & Düsseldorf & 572,171 \\
\hline 10 & Bremen & 549,157 \\
\hline 11 & Duisburg & 535,473 \\
\hline 12 & Leipzig & 524,870 \\
\hline 13 & Hannover & 523,574 \\
\hline 14 & Dresden & 496,863 \\
\hline 15 & Nürnberg & 493,940 \\
\hline 16 & Bochum & 400,608 \\
\hline 17 & Wuppertal & 382,600 \\
\hline 18 & Saarbrücken Stadtverband & 358,365 \\
\hline 19 & Bielefeld & 324,115 \\
\hline 20 & Mannheim Universitätsstadt & 313,880 \\
\hline 21 & Gelsenkirchen & 292,061 \\
\hline 22 & Bonn & 291,863 \\
\hline 23 & Chemnitz & 291,331 \\
\hline 24 & Halle (Saale) & 287,052 \\
\hline 25 & Karlsruhe & 276,544 \\
\hline 26 & Wiesbaden & 266,532 \\
\hline 27 & Mönchengladbach & 266,095 \\
\hline 28 & Münster & 264,696 \\
\hline 29 & Magdeburg & 262,557 \\
\hline 30 & Augsburg & 260,952 \\
\hline 31 & Braunschweig & 253,513 \\
\hline 32 & Krefeld & 249,821 \\
\hline 33 & Aachen & 247,460 \\
\hline 34 & Kiel & 246,595 \\
\hline 35 & Rostock & 230,768 \\
\hline 36 & Oberhausen & 224,896 \\
\hline 37 & Lübeck Hansestadt & 216,933 \\
\hline 38 & Hagen & 212,909 \\
\hline 39 & Erfurt & 212,532 \\
\hline 40 & Kassel & 201,628 \\
\hline 41 & Freiburg im Breisgau & 198,394 \\
\hline 42 & Mainz & 184,329 \\
\hline 43 & Hamm & 183,734 \\
\hline 44 & Herne & 179,973 \\
\hline 45 & Mülheim an der Ruhr & 176,602 \\
\hline 46 & Osnabrück & 168,106 \\
\hline 47 & Ludwigshafen am Rhein & 167,872 \\
\hline 48 & Solingen & 165,794 \\
\hline 49 & Leverkusen & 162,051 \\
\hline 50 & Oldenburg (Oldenburg) & 150,540 \\
\hline 51 & Potsdam & 144,941 \\
\hline 52 & Darmstadt & 138,973 \\
\hline 53 & Heidelberg & 138,612 \\
\hline 54 & Bremerhaven & 130,720 \\
\hline 55 & Cottbus & 127,791 \\
\hline 56 & Würzburg & 127,627 \\
\hline 57 & Wolfsburg & 126,782 \\
\hline 58 & Regensburg & 125,809 \\
\hline 59 & Gera & 124,971 \\
\hline 60 & Remscheid & 122,710 \\
\hline
\end{tabular}




\begin{tabular}{|c|c|c|}
\hline 61 & Heilbronn & 121,745 \\
\hline 62 & Bottrop & 120,008 \\
\hline 63 & Pforzheim & 118,460 \\
\hline 64 & Salzgitter & 117,776 \\
\hline 65 & Schwerin & 116,876 \\
\hline 66 & Offenbach am Main & 116,460 \\
\hline 67 & Ulm Universitätsstadt & 115,379 \\
\hline 68 & Zwickau & 112,646 \\
\hline 69 & Ingolstadt & 111,626 \\
\hline 70 & Koblenz & 109,292 \\
\hline 71 & Fürth & 108,011 \\
\hline 72 & Kaiserslautern & 101,970 \\
\hline 73 & Jena & 101,724 \\
\hline 74 & Erlangen & 101,372 \\
\hline 75 & Trier & 99,379 \\
\hline 76 & Dessau & 92,030 \\
\hline 77 & Wilhelmshaven & 90,944 \\
\hline 78 & Brandenburg an der Havel & 87,713 \\
\hline 79 & Flensburg & 87,642 \\
\hline 80 & Neumünster & 82,030 \\
\hline 81 & Neubrandenburg & 81,786 \\
\hline 82 & Frankfurt (Oder) & 81,633 \\
\hline 83 & Worms & 79,737 \\
\hline 84 & Delmenhorst & 78,079 \\
\hline 85 & Plauen & 73,318 \\
\hline 86 & Bayreuth & 72,692 \\
\hline 87 & Bamberg & 69,901 \\
\hline 88 & Görlitz & 68,773 \\
\hline 89 & Stralsund & 66,944 \\
\hline 90 & Aschaffenburg & 66,339 \\
\hline 91 & Weimar & 62,257 \\
\hline 92 & Greifswald & 61,688 \\
\hline 93 & Kempten (Allgäu) & 61,494 \\
\hline 94 & Hoyerswerda & 61,441 \\
\hline 95 & Landshut & 59,257 \\
\hline 96 & Rosenheim & 58,704 \\
\hline 97 & Schweinfurt & 55,598 \\
\hline 98 & Suhl & 53,986 \\
\hline 99 & Neustadt an der Weinstraße & 53,828 \\
\hline 100 & Baden-Baden & 52,677 \\
\hline 101 & Hof & 52,628 \\
\hline 102 & Emden & 51,653 \\
\hline 103 & Passau & 51,035 \\
\hline 104 & Wismar & 50,870 \\
\hline 105 & Speyer & 49,575 \\
\hline 106 & Pirmasens & 48,562 \\
\hline 107 & Frankenthal (Pfalz) & 47,946 \\
\hline 108 & Eisenach & 45,642 \\
\hline 109 & Amberg & 44,177 \\
\hline 110 & Straubing & 44,022 \\
\hline 111 & Coburg & 43,948 \\
\hline 112 & Weiden i.d.OPf. & 43,171 \\
\hline 113 & Kaufbeuren & 42,694 \\
\hline 114 & Memmingen & 40,492 \\
\hline 115 & Ansbach & 39,638 \\
\hline 116 & Landau in der Pfalz & 39,632 \\
\hline 117 & Schwabach & 37,564 \\
\hline 118 & Zweibrücken & 36,039 \\
\hline
\end{tabular}

Source: ARBEITSKREIS VOLKSWIRTSCHAFTLICHE GESAMTRECHNUNG DER LÄNDER (2007b). 


\section{Literature}

AHLFELDT, G. \& MAENNIG, W. (2007a). The Impact of Sports Arenas on Land Values: Evidence from Berlin. Annals of Regional Science, http://dx.doi.org/10.1007/s00168-0080249-4.

AHLFELDT, G. \& MAENNIG, W. (2007b). The Role of Architecture on Urban Revitalisation: The Case Of "Olympic Arenas" In Berlin-Prenzlauer Berg. Urban Studies (forthcoming).

ARBEITSKREIS VOLKSWIRTSCHAFTLICHE GESAMTRECHNUNGEN DER LÄNDER (2007a). Compensation of Employees, Gross Wages and Salaries in Germany on Nuts3-Level 1996 to 2005 [Electronic Version]. Retrieved 12th November 2007 from http://www.vgrdl.de/Arbeitskreis_VGR/R2B2.zip.

ARBEITSKREIS VOLKSWIRTSCHAFTLICHE GESAMTRECHNUNGEN DER LÄNDER (2007b). Income of Private Households in Germany on Nuts3-Level 1995 to 2005 [Electronic Version]. Retrieved 12th November 2007 from http://www.vgrdl.de/Arbeitskreis_VGR /R2B3.zip.

ATKINSON, G., MOURATO, S., SZYMANSKI, S. \& OZDEMIROGLU, E. (2008). Are We Willing to Pay Enough to 'Back the Bid'?: Valuing the Intangible Impacts of London's Bid to Host the 2012 Summer Olympic Games. Urban Studies, 45(2), 419-444.

BAADE, R. A. (1987). Is There an Economic Rationale for Subsidizing Sports Stadiums? Heartland Policy Study No.13.

BAADE, R. A. (1994). Stadiums, Professional Sports, and Economic Development: Assessing the Reality. Heartland Policy Study, No. 62.

BAADE, R. A. (1996). Professional Sports as Catalysts for Metropolitan Economic Development. Journal of Urban Affairs, 18(1), 1-17.

BAADE, R. A. \& DYE, R. F. (1990). The Impact of Stadiums and Professional Sports on Metropolitan Area Development. Growth and Change, 21(2), 1-14.

BAADE, R. A. \& SANDERSON, A. R. (1997). The Employment Effect of Teams and Sports Facilities. In R. G. NOLL \& A. ZIMBALIST (Eds.), Sports, Jobs, and Taxes: The Economic Impact of Sports Teams and Stadiums (pp. 92-118). Washington, D.C: Brookings Institution Press.

BALTAGI, B. H. (2001). Econometric Analysis of Panel Data (2 ed.). New York: Wiley \& Sons.

BERTRAND, M., DUFLO, E. \& MULLAINATHAN, S. (2004). How Much Should We Trust Differences-in-Differences Estimates? Quarterly Journal of Economics, 119(1), 249-275.

BÜTTNER, N., MAENNIG, W. \& MENßEN, M. (2005). Zur Ableitung einfacher Multiplikatoren für die Planung von Infrastrukturkosten anhand der Aufwendungen für Sportstätten - Eine Untersuchung anhand der Fußball-WM 2006. Hamburg Contemporary Economic Policy, No. 04/2005.

CARLINO, G. \& COULSON, N. E. (2004). Compensating Differentials and the Social Benefits of the NFL. Journal of Urban Economics, 56(1), 25-50.

COATES, D. \& HUMPHREYS, B. R. (1999). The Growth Effects of Sport Franchises, Stadia, and Arenas. Journal of Policy Analysis and Management, 18(4), 601-624.

COATES, D. \& HUMPHREYS, B. R. (2000). The Stadium Gambit and Local Economic Development. Regulation: The Cato Review of Business and Government, 23(2), 15-20. 
COATES, D. \& HUMPHREYS, B. R. (2001). The Economic Consequences of Professional Sports Strikes and Lockouts. Southern Economic Journal, 67(3), 737-747.

COATES, D. \& HUMPHREYS, B. R. (2003). Professional Sports Facilities, Franchises and Urban Economic Development. Public Finance and Management, 3(3), 335-357.

FEDDERSEN, A. \& MAENNIG, W. (2008). The European Perspective on Team Ownership, Competitive Balance, and Event Impacts. In B. R. HUMPHREYS \& D. R. HOWARD (Eds.), The Business of Sports (Vol. 1, Perspectives on the Sports Industry). Portsmouth, $\mathrm{NH}$ : Praeger.

FIFA (2006). World Cup 2006 in Germany, Stadia [Electronic Version]. Retrieved 12th May 2006 from http://fifaworldcup.yahoo.com/06/de/d/stadium/index.html.

HAGN, F. \& MAENNIG, W. (2008a). Labour Market Effects of the 2006 Soccer World Cup in Germany. Applied Economics, http://dx.doi.org/10.1080/00036840701604545.

HAGN, F. \& MAENNIG, W. (2008b). Short-Term to Long-Term Employment Effects of the Football World Cup 1974 in Germany. Labour Economics, 15(5), 1062-1075.

HEYNE, M., MAENNIG, W. \& SÜßMUTH, B. (2007). Mega-Sporting Events as Experience Goods. Hamburg Contemporary Economic Policy, No. 05.

HOTCHKISS, J. L., MOORE, R. E. \& ZOBAY, S. M. (2003). Impact of the 1996 Summer Olympic Games on Employment and Wages in Georgia. Southern Economic Journal, 69(3), 691-704.

JASMAND, S. \& MAENNIG, W. (2008). Regional Income and Employment Effects of the 1972 Munich Olympic Summer Games. Regional Studies, 42(7), 991-1002.

MAENNIG, W. (2006). Ikonen statt Schüsseln [Icons Instead Of "Bowls"]. Immobilienmanger, 7-8, 32-34.

MAENNIG, W. \& PORSCHE, M. (2008). The Feel-Good Effect at Mega Sports Events. Recommendations for Public and Private Administration Informed by the Experience of the Fifa World Cup 2006. Hamburg Contemporary Economic Policy, No. 18.

MELANIPHY, J. C. (1996). The Impact of Stadiums and Arenas. Real Estate Issues, 21(3), 3639.

NELSON, A. C. (2001). Prosperity or Bligth? A Question of Major League Stadia Locations. Economic Developmet Quarterly, 15(3), 255-265.

SANTEE, E. E. (1996). Major League Cities. Real Estate Issues, 21(3), 31-35.

SKRENTNY, W. (2001). Das große Buch der Deutschen Fußball-Stadien [the Allmanach of the German Soccer Stadia] (2 ed.). Göttingen: Verlag Die Werkstatt.

STADIONWELT (2007). Stadion. Neu- und Umbau [Stadia. New and Reconstruction] [Electronic Version]. Retrieved 26th November 2007 from http://www.stadionwelt.de/neu /sw_stadien/index.php?folder=sites\&site=neubau_d.

TU, C. C. (2005). How Does a New Sports Stadium Affect Housing Values? The Case of Fedex Field. Land Economics, 81(3), 379-395. 


\section{Hamburg Contemporary Economic Discussions}

(Download: http://www.uni-hamburg.de/economicpolicy/discussions.html)

01/2005 FEDDERSEN, A. / MAENNIG, W.: Trends in Competitive Balance: Is there Evidence for Growing Imbalance in Professional Sport Leagues?, January 2005.

02/2005 SIEVERS, T.: Information-driven Clustering - An Alternative to the Knowledge Spillover Story, February 2005.

03/2005 SIEVERS, T.: A Vector-based Approach to Modeling Knowledge in Economics, February 2005.

04/2005 BUETTNER, N. / MAENNIG, W. / MENSSEN, M.: Zur Ableitung einfacher Multiplikatoren für die Planung von Infrastrukturkosten anhand der Aufwendungen für Sportstätten - eine Untersuchung anhand der Fußball-WM 2006, May 2005.

01/2006 FEDDERSEN, A.: Economic Consequences of the UEFA Champions League for National Championships - The Case of Germany, May 2006.

02/2006 FEDDERSEN, A.: Measuring Between-season Competitive Balance with Markov Chains, July 2006.

03/2006 FEDDERSEN, A. / VÖPEL, H.: Staatliche Hilfen für Profifußballclubs in finanziellen Notlagen? - Die Kommunen im Konflikt zwischen Imageeffekten und Moral-Hazard-Problemen, September 2006.

04/2006 MAENNIG, W. / SCHWARTHOFF, F.: Stadium Architecture and Regional Economic Development: International Experience and the Plans of Durban, October 2006. 


\section{Hamburg Contemporary Economic Discussions}

(Download: http://www.uni-hamburg.de/economicpolicy/discussions.html)

01

02

03

04

05

06

07

08

O9

10

11

12

13

AHLFELDT, G. / MAENNIG, W.: The Role of Architecture on Urban Revitalization: The Case of "Olympic Arenas" in Berlin-Prenzlauer Berg, 2007.

FEDDERSEN, A. / MAENNIG, W. / ZIMMERMANN, P.: How to Win the Olympic Games - The Empirics of Key Success Factors of Olympic Bids, 2007.

AHLFELDT, G. / MAENNIG, W.: The Impact of Sports Arenas on Land Values: Evidence from Berlin, 2007.

DU PLESSIS, S. / MAENNIG, W.: World Cup 2010: South African Economic Perspectives and Policy Challenges Informed by the Experience of Germany 2006, 2007.

HEYNE, M. / MAENNIG, W. / SUESSMUTH, B.: Mega-sporting Events as Experience Goods, 2007.

DUST, L. I MAENNIG, W.: Shrinking and Growing Metropolitan Areas - Asymmetric Real Estate Price Reactions? The Case of German Single-family Houses, 2007.

JASMAND, S. / MAENNIG, W.: Regional Income and Employment Effects of the 1972 Munich Olympic Summer Games, 2007.

HAGN, F. / MAENNIG W.: Labour Market Effects of the 2006 Soccer World Cup in Germany, 2007.

HAGN, F. / MAENNIG, W.: Employment Effects of the World Cup 1974 in Germany.

MAENNIG, W.: One Year Later: A Re-appraisal of the Economics of the 2006 Soccer World Cup, 2007.

AHLFELDT, G., MAENNIG, W.: Assessing External Effects of City Airports: Land Values in Berlin, 2007.

AHLFELDT, G.: If Alonso was Right: Accessibility as Determinant for Attractiveness of Urban Location, 2007.

AHLFELDT, G.: A New Central Station for a Unified City: Predicting Impact on Property Prices for Urban Railway Network Extension, 2007. 


\section{Hamburg Contemporary Economic Discussions}

(Download: http://www.uni-hamburg.de/economicpolicy/discussions.html)

14

15

16
FEDDERSEN, A. / MAENNIG, W.: Arenas vs. Multifunctional Stadia Which Do Spectators Prefer?, 2007.

AHLFELDT, G. / FEDDERSEN, A.: Geography of a Sports Metropolis, 2007.

FEDDERSEN, A. / GRÖTZINGER, A. / MAENNIG, W.: New Stadia and Regional Economic Development - Evidence from FIFA World Cup 2006 Stadia, 2008. 

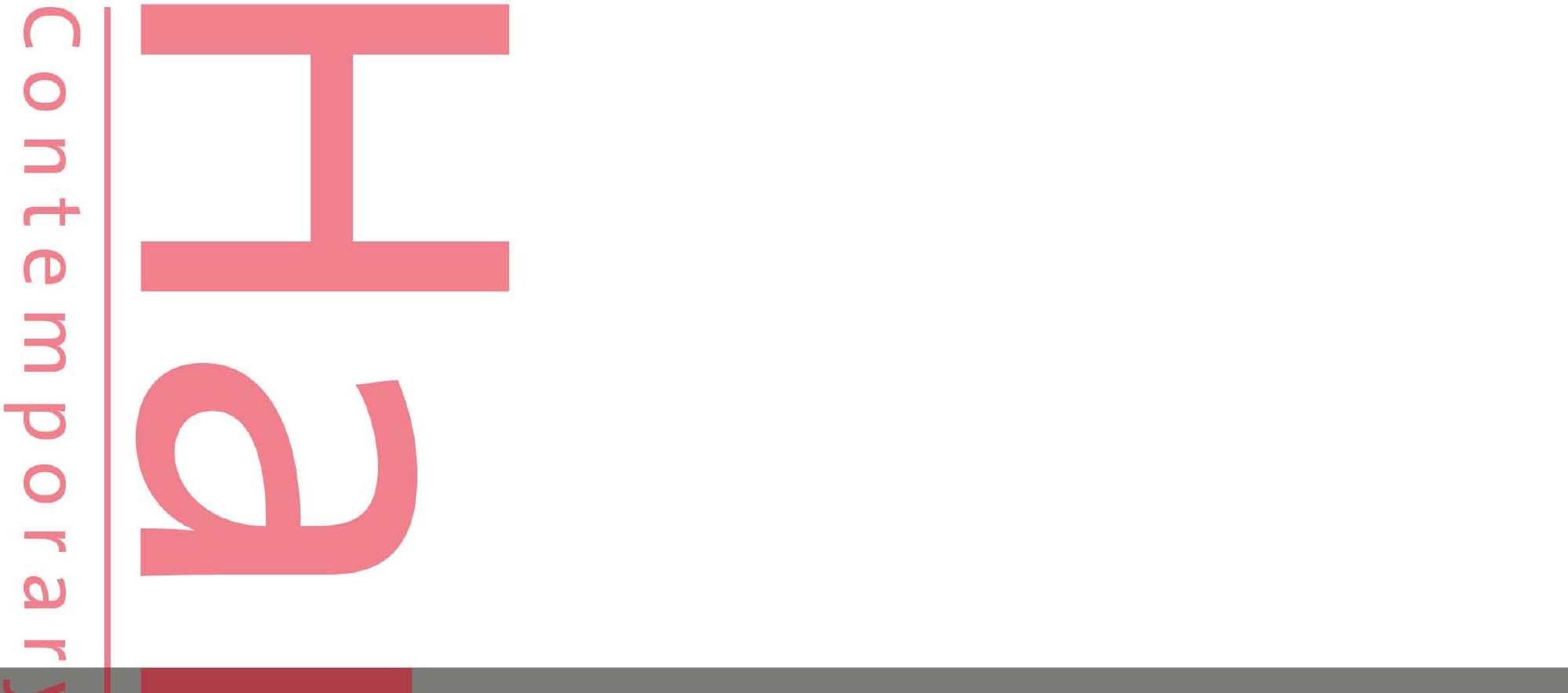

ISSN 1865-2441 (PRINT) ISSN 1865-7133 (ONLINE)

ISBN 978-3-940369-46-8 (PRINT) ISBN 978-3-940369-47-5 (ONLINE) 